\title{
Polska literatura obozowa. Kilka pytań o syntezę, której nie ma
}

Co najmniej trzy powody decydują o tym, że wciąż brak historycznoliterackiej syntezy dotyczącej polskiej literatury obozowej. Pierwszy powód to lagrowa proza Tadeusza Borowskiego. Powód drugi to pisana po polsku literatura Holokaustu. Powód trzeci jest konsekwencją różnic między literaturą obozową pisaną w kraju i na emigracji.

\section{Protosyntezy polskiej literatury lagrowej}

Sytuację dodatkowo komplikuje fakt, że nieobecności syntezy polskiej literatury lagrowej towarzyszy obecność syntez, a przynajmniej protosyntez polskiej literatury łagrowej. Chodzi mi zarówno o różnie ocenianą pracę Eugeniusza Czaplejewicza' ${ }^{1}$, monografię Izabelli Sariusz-Skąpskiej Polscy świadkowie GUŁagu ${ }^{2}$, jak i o publikacje bardziej specjalistyczne, partykularne, na przykład Doświadczenie Boga w Gułagu dominikanina Andrzeja Morki³. Syntezy/protosyntezy polskiej literatury łagrowej są, ponieważ najważniejszy jej twórca, Gustaw Herling-Grudziński, nie jest autorem innym od pozostałych, którzy zajmują się tą problematyką. Jego wizja łagrów odpowiada tej, jaką zapisali pozostali polscy pisarze ${ }^{4}$, jest heroiczna i martyrologiczna, humanistyczna i moralistyczna, polska. Jej spójności,

* Dr hab., prof. nadzw., Uniwersytet w Białymstoku, Instytut Filologii Polskiej, Zakład Literatury Międzywojennej i Współczesnej; Pl. Uniwersytecki 1, 15-420 Białystok; ifp@uwb.edu.pl.

${ }^{1}$ Zob. E. Czaplejewicz, Polska literatura łagrowa, Wydawnictwo Naukowe PWN, Warszawa 1992.

${ }^{2}$ Zob. I. Sariusz-Skąpska, Polscy świadkowie GUŁagu. Literatura łagrowa 1939-1989, Universitas, wyd. 3, Kraków 2012. Pierwodr.: 1995, wyd. 2: 2002.

${ }^{3}$ Zob. A. Morka, Doświadczenie Boga w Gułagu, Wydawnictwo i Drukarnia Diecezji Sandomierskiej, Sandomierz 2007.

${ }^{4}$ Powtarzalności, trwałości tej wizji nie zmieniają takie teksty jak powieść Mariana Czuchnowskiego Tyfus, teraz słowiki (Londyn 1951), ale opowiada ona nie tyle o obozie, ile o sowieckim szpitalu, a miejsce to nawet w prozie Borowskiego, jak w całej literaturze lagrowo-łagrowej, często bywa azylem w morzu obozowej śmierci. 
inaczej niż w przypadku literatury lagrowej, nie narusza doświadczenie porównywalne z Holokaustem. Poza tym o polskiej literaturze łagrowej, o jej jednorodności, z powodów politycznej natury, zdecydowali pisarze emigracyjni.

Wymienione argumenty, które antytetycznie nawiązują do powodów nieistnienia syntezy polskiej literatury obozowej, można uzupełnić innymi. Ograniczę się do dwóch, dodatkowych, nieostrych i kontrowersyjnych, pośrednio wpływających na istnienie syntetycznych omówień literatury łagrowej. Pierwszy: pisanie o emigracyjnej beletrystyce, a zwłaszcza o literaturze łagrowej, nie tylko fikcjonalnej, determinowane jest po roku 1989 przez szczególne zobowiązanie wobec jej twórców: nieobecnych w kraju po 1944 roku, w kraju i w krajowym literaturoznawstwie. Pisanie to jest uwalnianiem się od poczucia winy i realizacją najlepiej rozumianej polonistycznej poprawności, czego szczególnie ważny przykład stanowi Próba scalenia Tadeusza Drewnowskiego ${ }^{5}$. Argument drugi: literatura łagrowa potwierdza nasze dobre mniemanie o sobie. Nie dość, że wpisuje się w romantyczny (martyrologiczny i mesjanistyczny) standard przeżywania przez nas historii, to jeszcze pozwala Polakom przeżywać na nowo swoją kulturalną wyższość nad sowieckim oprawcą.

\section{Tadeusz Borowski}

Choć ze względu na wyjątkowość tematu nie brzmi to właściwie, w istocie niewiele jest nonszalancji w stwierdzeniu: po co nam synteza polskiej literatury obozowej, skoro wciąż przybywa nam omówień lagrowej prozy Tadeusza Borowskiego. Przecież każdy tekst, zwłaszcza literacki, podejmujący problematykę obozową dzieje się, jest, bywa, a nawet powinien być czytany wobec, w konfrontacji z Pożegnaniem z Maria i Kamiennym światem. Polska literatura obozowa to Borowski, ponieważ nikt nie powiedział o obozach więcej i nie zrobił tego, korzystając z bardziej oryginalnych i adekwatnych rozwiązań literackich.

Powiedzieć najwięcej oznacza przede wszystkim sięgnąć do istoty obozowego doświadczenia, do niewyobrażalnej, perfekcyjnie zorganizowanej zbrodni, która zmienia granice człowieczeństwa, obciążając nie tylko oprawców, ale także ofiary, a ponadto stanowi moralne wyzwanie dla wszystkich, którym dane było zetknąć się z nią, także za pośrednictwem literatury. Powiedzieć najwięcej to także napisać dzieło fragmentaryczne, podzielone na opowiadania (Pożegnanie z Maria) i nowele (Kamienny świat), ale w istocie epickie, czyli pozwalające na rekonstrukcję

${ }^{5}$ Zob. T. Drewnowski, Próba scalenia. Obiegi - wzorce - style, Wydawnictwo Naukowe PWN, Warszawa 1997. Zob. tenże, Literatura polska 1944-1989. Próba scalenia: obiegi-wzorce - style, wyd. 2 popr. i uzup., Universitas, Kraków 2004. 
obozowej gehenny od przybycia na rampę Auschwitz (na przykład Prosze państwa do gazu), poprzez eksterminację węgierskich Żydów (Ludzie, którzy szli), aż po dwuznaczne wyzwolenie (na przykład Milczenie) i pobyt w obozie dla dipisów (na przykład Spotkanie z dzieckiem albo Bitwa pod Grunwaldem).

Od lat wracam do tezy, że warunkiem funkcjonowania literatury polskiej po wojnie było jej zapisanie, wymagające spełnienia dwóch warunków. Należało pokazywać wojenno-okupacyjne jądro ciemności i to w sposób, jaki do tej pory przez polskich pisarzy nie był stosowany. Najwięcej zrobili w tym względzie Tadeusz Różewicz i Borowski. Pierwszego, ponieważ chodzi o problematykę obozową, zmuszony jestem pominąć. Drugi zapisał obóz najpełniej, najbardziej oryginalnie i adekwatnie, wykorzystując niepraktykowaną dotąd na taką skalę w literaturze polskiej technikę behawioralną ${ }^{6}$. Dzięki temu pozwolił literaturze polskiej funkcjonować po wojnie.

Cała polska literatura obozowa wobec lagrowych tekstów Borowskiego jest albo drugorzędna, albo wtórna. Już w 1971 roku$^{7}$ relację między Pożegnaniem z Maria i pozostałą literaturą obozową ustalił Andrzej Werner, wprowadzając kategorię „literatura martyrologiczna". Od opublikowania Zwyczajnej apokalip$s y$ jest albo Borowski, albo rzesza autorów bezradnych w konfrontacji z obozowym doświadczeniem, powielających wobec lagrów romantyczne wzorce oswajania narodowych klęsk. Rezultaty ich wysiłków Tadeusz Borowski jako pisarz zdyskredytował m.in. w Bitwie pod Grunwaldem, a jako krytyk literacki w Alicji z krainy czarów ${ }^{9}$.

Z czasem polska literatura obozowa przestała być wyłącznie martyrologiczna, ale sąd ten wydaje się raczej życzeniowy niż oddający realny, aktualny stan rzeczy. Bo jakie teksty można przywołać, żeby go potwierdzić? Czy wystarczy $Z$ Auszwicu do Belsen Mariana Pankowskiego ${ }^{10}$, emigranta oryginalnego, bo ani paryskiego, ani londyńskiego czy nowojorskiego, ale osobnego, brukselskiego. Sytuacja wygląda inaczej. Literatura obozowa nie tyle przestała być martyrologiczna, ile zaczęła być doceniana, a w każdym razie traktowana jako ,specyficzna odmiana pisarstwa historycznego"11. Zmianę tę w dużej mierze spowodowała

\footnotetext{
${ }^{6}$ Więcej piszę o tym w książce Dwie prawdy. Tadeusz Borowski i Zofia Kossak wobec obrazu wojny w polskiej prozie lat 1944-1948 (Trans Humana, Białystok 2006).

7 ,Już” z perspektywy wieku XXI, ale „dopiero” z punktu widzenia daty zakończenia drugiej wojny światowej.

${ }^{8}$ Zob. A. Werner, Zwyczajna apokalipsa. Tadeusz Borowski i jego wizja świata obozów, Czytelnik, Warszawa 1971.

${ }^{9}$ Zob. T. Borowski, Alicja w krainie czarów, „Pokolenie” 1947, nr 1. Pierwsza edycja książkowa recenzji w: tenże, Utwory zebrane, red. nacz. J. Andrzejewski, t. 3: Krytyka literacka i artystyczna, Państwowy Instytut Wydawniczy, Warszawa 1954, s. 21-31.

${ }^{10}$ Zob. M. Pankowski, Z Auszwicu do Belsen. Przygody, Czytelnik, Warszawa 2000.

${ }^{11}$ Zob. B. Krupa, Wspomnienia obozowe jako specyficzna odmiana pisarstwa historycznego, Universitas, Kraków 2006.
} 
książka Bartłomieja Krupy, ufundowana m.in. na przeświadczeniu, że wyjątkowość Holokaustu nadaje każdemu utworowi, który go dotyczy, niezależnie od jego wartości literackiej, status bezcennego dokumentu i nieocenionego świadectwa. Takie, uzasadnione traktowanie Szoa miało przynajmniej pośredni wpływ na oceny polskiej literatury lagrowej o martyrologicznym charakterze ${ }^{12}$.

\section{Holokaust}

Borowski, zapisując apokaliptyczny fenomen obozów koncentracyjnych, nie wyeksponował w nim wyjątkowego losu Żydów o tyle, o ile był on dla niego częścią spójnej wizji lagrowej rzeczywistości. W konsekwencji obóz pochłonął Holokaust. A literatura polska, dysponując arcydzielną lagrową beletrystyką, nie zapisała Zagłady, nie poradziła sobie $\mathrm{z}$ nią. $\mathrm{Z}$ jednym zastrzeżeniem: ten sąd nie dotyczy ani pisarzy polskich żydowskiego pochodzenia, ani pisarzy żydowskich pochodzenia polskiego ${ }^{13}$, ponieważ w ich przypadku nie mamy co prawda do czynienia z literaturą opisującą obóz, ale z tekstami wiarygodnymi wobec doświadczenia Szoa ${ }^{14}$.

Sytuacja wygląda zatem tak: z jednej strony zapisany obóz, który bywa traktowany jako znak Zagłady, chociaż jego obraz w literaturze polskiej zasadności tego znaku nie potwierdza, ponieważ skupia się albo na heroicznym męczeństwie Polaków (literatura martyrologiczna), albo na odczłowieczającym wszystkich: zarówno oprawców, jak i ofiary, perfekcyjnym działaniu obozowego mechanizmu (Borowski), natomiast druga strona to pisana przez Żydów, w różny sposób związanych z Polską, literatura Holokaustu, w której obóz, jeśli w ogóle się pojawia, odgrywa rolę drugorzędną ${ }^{15}$.

12 Paradoks polega na tym, że literatura skupiona na martyrologii Polaków nie bierze pod uwagę wyjątkowości obozowego losu Żydów.

${ }^{13}$ Zob. Pisarze polsko-żydowscy XX wieku. Przybliżenia, pod red. M. Dąbrowskiego i A. Molisak, Elipsa, Warszawa 2006. W tej monografii zbiorowej po raz kolejny wraca się do podziału na pisarzy polskich żydowskiego pochodzenia i pisarzy żydowskich pochodzenia polskiego. Pierwszych w przejmujący sposób opisał Artur Sandauer w książce, która powstała na podstawie słynnego artykułu opublikowanego na łamach „Życia Literackiego”, książce zatytułowanej tak samo jak artykuł: O sytuacji pisarza polskiego pochodzenia żydowskiego wXX wieku (rzecz, która nie ja powinienem byt napisać...), Czytelnik, Warszawa 1982. Z drugimi identyfikował się Bogdan Wojdowski, autor m.in. znakomitej, epickiej powieści o getcie warszawskim: Chleb rzucony umarlym i tylko nieco mniej znanego tekstu Judaizm jako los („Puls” 1993, nr 3).

${ }^{14} \mathrm{O}$ tekstach tych pisałem w rozdziale Polska proza o Zagładzie i emocje. Rekonesans, będącym częścią mojej książki W poszukiwaniu istoty rzeczy. Studia i portrety (Katedra Badań Filologicznych „Wschód-Zachód”. Wydział Filologiczny, Białystok 2015).

${ }^{15}$ Nawet, jeśli bywa przerażającym punktem odniesienia, jak w Oczekiwaniu Jerzego Broszkiewicza (Wiedza, Warszawa 1948). 
Niestety, równanie to (jedna strona, druga strona) nie ma w sobie nic z kojącej, dialektycznej stabilności. Wprost przeciwnie, jest w nim dysproporcja i dysonans. Dysproporcja dotyczy relacji między zapisaniem wojny, zapisaniem obozu i niezapisaniem Holokaustu. Wygląda na to, że oszukaliśmy historię, literaturę i samych siebie: my, Polacy. Oszukaliśmy, zapisując wojnę dzięki lagrowej prozie Borowskiego, ale bez uporania się, a nawet bez zmierzenia się z Zagładą ${ }^{16}$. Jak to się mogło stać? Jak można było stworzyć iluzję zapisania wojny bez zapisania Szoa? Odpowiedzi nadużywające w tej sprawie problemu traumy (nie)przedstawionej ${ }^{17}$ nie wydają mi się wystarczające. Jedyne usprawiedliwienie/uzasadnienie tego stanu rzeczy znajduję w arcydzielności lagrowej prozy Tadeusza Borowskiego i w tym, że jej autor, nadzwyczaj przenikliwie dostrzegający mechanizmy funkcjonowania KL Auschwitz-Birkenau, które skutecznie niszczyły śródziemnomorską cywilizację, właśnie na nich był skupiony.

Nie zmienia to jednak faktu, że dysonans pozostaje. Dysonans między żydowskim, lagrowym losem i prozą Borowskiego, a w konsekwencji między polską literaturą obozową i polsko-żydowską literaturą Holokaustu. Pierwsza, w całości może być opatrzona mottem „Ludzie ludziom zgotowali ten los”. Druga, nie tylko wówczas, gdy można przypisać ją Henrykowi Grynbergowi, powinna być opatrzona zdaniem „Ludzie Żydom zgotowali ten los”. Bo obóz, najdoskonalej nawet opisany, nie jest w stanie pochłonąć Zagłady. Nie może jej przesłonić. Nie wiem, czy jest możliwa literatura poświęcona Szoa dotycząca obozu, która go marginalizuje. W tym miejscu, w tym tekście mogę jedynie wskazać problem dysproporcji i dysonansu, który, dotycząc lagrów i Zagłady, literatury polskiej i polsko-żydowskiej, jest poważny na tyle, że bez uporania się z nim wiarygodna synteza literatury obozowej powstać w naszym kraju nie może.

\section{Kraj i emigracja}

Obóz z prozy Borowskiego to patologiczny rezultat śródziemnomorskiej kultury, do której przyznawał się narrator $U$ nas, w Auschwitzu... Dlatego koncentracyjna katastrofa była dla niego czymś, czego nie traktował jako wydarzenia

\footnotetext{
${ }^{16}$ Adolf Rudnicki miał świadomość konieczności pisania o Zagładzie i pisarskiej bezradności wobec tego tematu (zob. A. Rudnicki, Piękna sztuka pisania, w: tenże, Szekspir, Książka, Warszawa 1948), ale nie ma powodu, by jego dramatem usprawiedliwiać pasywność wobec Szoa autorów polskiego pochodzenia. Literaturę polską tworzą w takim samym stopniu pisarze polscy, jak polsko-żydowscy, a wskazywanie literackich problemów którejkolwiek z tych grup nie powinno być traktowane jako zachowanie niestosowne. Uwaga ta w równym stopniu dotyczy tego, co zostało już w tym tekście napisane, jak i tego, co napisane w nim jeszcze zostanie.

${ }^{17}$ Zob. „Teksty Drugie” 2004, nr 5.
} 
z innego świata. To był nie tylko problem Zachodu, ale także jego, problem studenta polonistyki na podziemnym uniwersytecie, esencjasty bawiącego się z przyjaciółmi, poety piszącego Homerowym heksametrem i więźnia Auschwitz ${ }^{18}$.

Literatura emigracyjna dotyczyła przede wszystkim łagrów i już jako taka nie da się bezkolizyjnie zestawić, a już na pewno razem opisać w jednej, obozowej syntezie. Upraszczając w niewielkim stopniu, można zaryzykować twierdzenie, że poza nielicznymi, lagrowymi wyjątkami (na przykład nieobozowo-obozowa proza Zofii Romanowiczowej) ${ }^{19}$ powiela ona martyrologiczny schemat znany z wydawanych w kraju zaraz po wojnie książek Seweryny Szmaglewskiej, Zofii Kossak czy Krystyny Żywulskiej ${ }^{20}$. A w konsekwencji pozostaje różna od tego, co o Auschwitz pisał Borowski. Literatura emigracyjna dotycząca łagrów, czyli na przykład teksty Gustawa Herlinga-Grudzińskiego, Beaty Obertyńskiej, Józefa Czapskiego, Herminii Naglerowej i Wacława Grubińskiego, niezależnie od wszystkich dzielących je różnic, łączy świadomość zapisywania obcego, innego świata, innego niż zachodni i europejski, czyli cywilizowany, świata wschodniego i azjatyckiego, czyli barbarzyńskiego. Tak jak obóz jest dla Borowskiego jego własnym problemem, jego osobistą, cywilizacyjną porażką, tak łagry pozostają dla polskich pisarzy problemem zewnętrznym, cudzym, którego konsekwencje - na nieludzkiej ziemi - pozostało nam, Polakom, heroicznie znosić. Stąd nawet w Innym świecie czy w Na nieludzkiej ziemi, a także we wspomnieniach $W$ domu niewoli i Między młotem i sierpem oraz w zbiorze Kazachstańskie noce tyle jawnego, a czasem wręcz irytującego poczucia wyższości wobec sowieckiej Rosji. Bo my przecież przynależymy do Zachodu i dobrze pamiętamy rok 1920.

Razem, pod tym samym tytułem, można opisać wszystko, ale różnice między krajową literaturą lagrową zdominowaną przez prozę Borowskiego i emigracyjną, szeroko rozumianą literaturą łagrową (dotyczącą losu Polaków na terytorium ZSRR od roku 1939 co najmniej po rok 1956) ${ }^{21}$ są tak zasadnicze, że trudno

${ }^{18}$ Opowiadanie $U$ nas, $w$ Auschwitzu... jest wyjątkowym tekstem wśród pozostałych próz obozowych Borowskiego. Tworzące je, zrekonstruowane wiernie listy pisane do narzeczonej, Marii Rundo, więźniarki Birkenau, pozwalają na refleksje dotyczące obozu, które zostały właściwie wyeliminowane w tekstach pozostałych, konsekwentnie behawioralnych. W sprawie wierności zrekonstruowanych listów zob. Pożegnanie z Tuśka, notowali Krystyna Bratkowska i Michał Cichy, „Gazeta Wyborcza” 1995, nr 24. W sprawie „Klubu Esencjastów” zob. T. Drewnowski, Ucieczka z kamiennego świata. O Tadeuszu Borowskim, wyd. 3, Państwowy Instytut Wydawniczy, Warszawa 1992, s. 67-71, oraz J. Szczęsna, Tadeusz Borowski - poeta, Poznańskie Studia Polonistyczne. Seria Literacka, Poznań 2002, s. 13-16. O pisanym heksametrem cyklu/tomiku Gdziekolwiek ziemia... wspominają zarówno Drewnowski, jak i Szczęsna.

${ }^{19}$ Zob. np. taż: Przejście przez Morze Czerwone, Lagodne oko błękitu, Trybulacje Proboszcza P.

${ }^{20}$ Zob. S. Szmaglewska, Dymy nad Birkenau, Czytelnik, Warszawa 1945; Z. Kossak, Z otchtani. Wspomnienia z lagru, Wydawnictwo Księgarni Wł. Nagłowskiego, Częstochowa-Poznań 1946 (oraz wersja zmieniona: Warszawa 1958); K. Żywulska, Przeżytam Oświęcim, Wiedza, Warszawa 1946.

${ }^{21}$ Zob. np. B. Skarga, Po wyzwoleniu... (1944-1956), wyd. 2 krajowe, W drodze, Poznań 1990. Pierwodr. paryski, pod pseudonimem Wiktoria Kraśniewska: 1985. 
oczekiwać literaturoznawczej syntezy opisującej je jako całość. A to tylko jedna $z$ trzech zasadniczych przyczyn utrudniających, a może uniemożliwiających powstanie syntetycznego, historycznoliterackiego omówienia polskiej literatury obozowej. Nie oznacza to jednak, że niczego nie można zrobić.

\section{To, co jest do zrobienia}

Wydaje się, że literaturę lagrową i łagrową należy opisywać osobno, ale sąd ten wymaga praktycznej weryfikacji. Póki co warto skupić się na literaturze lagrowej, która syntezy nie posiada, warto uporządkować ją zarówno według kryteriów pozaliterackiej, jak i literackiej natury. Te pierwsze (pozaliterackie) proponuję podzielić na historyczne (jakie obozy i kiedy?) oraz geograficzne (gdzie?), drugie, literackie powinny uwzględniać kwestie periodyzacyjne (jakie teksty obozowe i kiedy?), genologiczne (dlaczego nieepicka proza?) i komparatystyczne (polska literatura obozowa wobec obozowej literatury Rosjan, Węgrów i Włochów).

\section{Kryteria pozaliterackie: historyczne i geograficzne}

Jakie obozy? Niemieckie obozy koncentracyjne (od Dymów... Szmaglewskiej po Borowskiego, tutaj literackich przykładów jest najwięcej), obozy dla dipisów (Borowski, Obóz Wszystkich Świętych Tadeusza Nowakowskiego z 1957 roku, Dziennik podróży do Austrii i Niemiec Pawła Hostowca, czyli Jerzego Stempowskiego z roku 1946), ale także obozy jenieckie (Kłamałem, aby żyć Aleksandra Janty-Połczyńskiego z 1945) i niemieckie obozy pracy (np. Strach z tomu Wielki cień Jerzego Pytlakowskiego z 1946), a także obozy, w których przetrzymywano mieszkańców Warszawy po upadku Powstania Warszawskiego (np. Wody z Wielkiego cienia albo trzeci fragment Próby śmierci z tomu Śmiertelni bohaterowie Witolda Zaleskiego z 1946) 22 .

Istnieje problem granic zastosowania tego kryterium, bo co na przykład zrobić z więzieniami opisanymi w Kracie Poli Gojawiczyńskiej (1945) albo w tekście Dwadzieścia cztery godziny śmierci Pytlakowskiego (Wielki cień raz jeszcze)? Nie jest to kwestia wyłącznie teoretyczna, ponieważ wynika z lektury także takich utworów jak Szopa za jaśminami Nowakowskiego (1948), gdzie mamy do czynienia nie tylko z niemieckim więzieniem we Włocławku, ale także z więzieniem w Zwickau (zorganizowaną przez Gestapo koedukacyjną przechowalnią dla

\footnotetext{
22 Pierwszy fragment Próby śmierci dotyczy powstańczego szpitala, drugi: obozu jenieckiego.
} 
szczególnie niebezpiecznych więźniów politycznych), z obozem przejściowym Gestapo w Inowrocławiu czy karnym obozem Elsnig-Vogelgesang nad Łabą.

Problemy można by zresztą mnożyć. Wolę jednak napisać, że przygotowanie do syntezy realizowane według zaproponowanych kryteriów pozwala uwolnić się od dominacji prozy Borowskiego, paraliżującej ocenę polskiej literatury obozowej. Dzieje się tak dlatego, że punktem wyjścia dla syntetyzowania są porządki historyczno-geograficzne, a nie wartościująco-literackie. Dzięki temu razem można umieścić nie tylko Pożegnanie z Maria i martyrologiczne, krajowe Dymy nad Birkenau, ale także teksty emigracyjne, zarówno obozowe (Nowakowski, Hostowiec, Janta-Połczyński), jak i łagrowe, niezależnie nawet od tego, że początkowo miały się w syntezie nie znaleźć. Przecież jeśli ma ona uwzględniać obozy jenieckie, to obok powieści Połczyńskiego i prozy Zalewskiego powinny się w niej znaleźć Wspomnienia starobielskie Czapskiego. Podobnie jest z niemieckimi obozami pracy, których opisanie w naturalny sposób wymaga kontekstu podobnych obozów funkcjonujących na terenie sowieckiej Rosji, opisywanych przez wymienianych już autorów literatury łagrowej, do grona których - ze względu na Książkę o Kotymie z 1950 roku - warto dodać Anatola Krakowieckiego.

Historia GUŁagu wciąż jest opowiadana i wciąż dopowiadana. Coraz więcej osób czyta już nie Archipelag GUŁag Aleksandra Sołżenicyna, ale Gułag Anne Appelbaum ${ }^{23}$. Efekt jest taki, że łagry mają swoją historię, a obozy nie ${ }^{24}$. Dlatego tak ważne wydaje się uporządkowanie i zapisanie podstawowej wiedzy historycznej, która lagrów dotyczy. Chodzi nie tylko o ich rodzaje, ale także o ich geografię, bo kto pamięta, że międzywojenna Polska w latach drugiej wojny światowej nie tylko traciła Kresy Wschodnie, ale także terytoria na zachodzie, z których Niemcy, przyłączając je do Rzeszy, utworzyli Kraj Warty. A kto z nas jest w stanie dokładnie określić granice Generalnego Gubernatorstwa? Nie chodzi wyłącznie o historyczną geografię, chodzi także o to, na jakim terytorium znajdował się KL Auschwitz-Birkenau. Czy na ziemiach anektowanych przez Rzeszę, czy w GG? Przecież od Oświęcimia do Krakowa, stolicy Generalnego Gubernatorstwa, jest niewiele ponad 60 kilometrów.

${ }^{23}$ Zob. A. Appelbaum, Gułag, przeł. J. Urbański [rozdz. 1 - M. Claire Wybieralska], Świat Książki, Warszawa 2005, oraz A. Sołżenicyn, Archipelag GUŁag 1918-1956. Próba analizy literackiej, cz. 1-2, przeł. M. Kaniowski, Instytut Literacki, Paryż 1974. Zob. też T. Kizny, Gułag, współpr. D. Roynette, wstęp N. Davies, S. Kowalow, N. Werth, IPN - Komisja Ścigania Zbrodni przeciwko Narodowi Polskiemu, Fundacja Pictura Doc, Warszawa 2015.

${ }^{24}$ Jest sygnowana przez Główną Komisję Badania Zbrodni Hitlerowskich w Polsce oraz przez Radę Ochrony Pomników Walki i Męczeństwa publikacja zatytułowana Obozy hitlerowskie na ziemiach polskich 1939-1945. Informator encyklopedyczny (Warszawa 1979), ale niezależnie od wszystkich zalet pochodzi ona z epoki, w której hasło o obozach hitlerowskich w Wielkiej encyklopedii powszechnej z 1967 roku zostało zmienione pod wpływem moczarowców, ponieważ za dużo było w nim o Żydach. Zob. Czas ciekawy, czas niespokojny. Z Leszkiem Kołakowskim rozmawia Zbigniew Mentzel, Znak, Kraków 2007, cz. 1, s. 256. 
Literacka mapa może uwzględniać podział administracyjny okupowanej Polski z lat 1939-1945 albo brać pod uwagę przedwojenne i/lub pojałtańskie granice naszego kraju. Już teraz wiadomo, że lagry od Auschwitz po Monachium na południu Niemiec (środkowoeuropejskie i zachodnioeuropejskie) zapisał najlepiej Borowski; łagry wschodniego, sowieckiego, europejsko-azjatyckiego terytorium najskuteczniej utrwaliły teksty Grudzińskiego, Czapskiego i Obertyńskiej (m.in. Ural i Uzbekistan) oraz Krakowieckiego (Kołyma) ${ }^{25}$; obozy środkowej Europy funkcjonujące między Wisłą i Łabą na osi wschód-zachód (zarówno w trakcie, jak i po zakończeniu wojny), to domena prozy Tadeusza Nowakowskiego; najdalej na zachód wysunięty punkt tej mapy wyznacza autobiograficzna powieść Janty-Połczyńskiego, notująca dzieje francuskich żołnierzy i udających ich Polaków, internowanych przez faszystowskie Niemcy.

\section{Kryteria literackie: genologia}

Historyczno-geograficzna mapa tekstów obozowych to pierwszy, podstawowy krok prowadzący do przygotowania syntezy polskiej literatury lagrowej, łagrowej i obozowej. Warunkiem historycznoliterackiego charakteru tego przedsięwzięcia jest uwzględnienie przy jego realizacji kryteriów literackiej natury. Zacznę od genologii, ponieważ nie należy dłużej zwlekać z oczywistym stwierdzeniem, że polska literatura obozowa to przede wszystkim proza. Obozowa poezja nie może z nią konkurować. Widać to wyraźnie nie tylko wówczas, gdy konfrontujemy polską obozową prozę z polską obozową poezją, ale także wtedy, gdy to samo rodzajowe porównanie przeprowadzimy $\mathrm{w}$ obrębie konkretnych twórczości, a chodzi o dorobek twórców tak ważnych jak Tadeusz Borowski i Beata Obertyńska.

Obozowe wiersze Borowskiego ${ }^{26}$ nie są w stanie konkurować z jego obozową prozą. Łagrowa poezja Obertyńskiej ${ }^{27}$, autorki $W$ domu niewoli, najbardziej epickiej opowieści o nie tylko obozowej gehennie Polaków na Wschodzie, też traci na znaczeniu wobec jej łagrowej prozy. I Obertyńska, i Borowski do czasu swoich doświadczeń obozowych bardziej byli znani jako poeci, a Borowski, nawet jako

${ }^{25}$ Grudziński to najważniejszy autor polskiej literatury łagrowej. Książki Czapskiego wyznaczają kanon losu polskich jeńców wojennych, kojarzony nieuchronnie ze zbrodnią katyńską. Beata Obertyńska zapisała w swojej prozie, $W$ domu niewoli, typowy los polskiej, kresowej (w tym wypadku lwowskiej) inteligencji, skazanej przez sowiecką władzę po 17 września 1939 na tułaczkę, więzienie i niewolniczą pracę. Książka o Kotymie Anatola Krakowieckiego to tekst intencjonalnie poświęcony największemu w sowieckiej Rosji kompleksowi obozów pracy, oczywiście wychowawczej.

${ }^{26}$ Zob. T. Borowski, Księga z dnia Wigilii, w: tenże, Poezja, oprac. T. Drewnowski, J. Szczęsna, Wydawnictwo Literackie, Kraków 2003.

${ }^{27}$ Zob. B. Obertyńska, Wiersze z łagrów, w: taż, W domu niewoli, Instytut Wydawniczy Pax, Warszawa 1991. Pierwodr.: 1946. 
współautor Byliśmy w Oświęcimiu, w kategoriach literackich traktował wyłącznie swoją poezję $e^{28}$. Nie ma powodu rozstrzygać, który z rodzajów literackich: proza czy poezja, jest bardziej adekwatny wobec obozowego doświadczenia. Wystarczy stwierdzić, że doświadczeniu temu proza sprostała skuteczniej niż poezja, dodając na marginesie następującą sugestię: może gotowe, martyrologiczno-mesjańskie wzorce romantycznej proweniencji, którymi literatura polska dysponowała (i dysponuje) wobec historycznych katastrof, po drugiej wojnie światowej okazały się trwalsze na polu poezji niż mniej oswojonej przez romantyzm prozy. Ale wytłumaczenie to, użyteczne w stosunku do antyromantycznego Borowskie$\mathrm{go}^{29}$, niezbyt sprawdza się wobec genetycznie romantycznej, obozowej literatury martyrologicznej. Istnieje i taka ewentualność, że o przewadze prozy w większym stopniu niż genologiczna teoria zdecydowała praktyka, i to zarówno literacka: behawioralna proza obozowa Borowskiego, jak i „obyczajowa”: naturalna skłonność (po)obozowej społeczności do spisywania swoich wspomnień w postaci tekstów prozatorskich raczej niż poetyckich.

Wiedząc, że proza, warto zapytać: jaka? Najpierw, żeby nie zawsze zaczynać od Borowskiego, powieści o epickich ambicjach, usiłujące ogarnąć całość obozowego doświadczenia, czyli Dymy nad Birkenau w kraju oraz $W$ domu niewoli na emigracji. Poza tym Inny świat Grudzińskiego, $Z$ otchłani Kossak, najpełniejsza edycja Na nieludzkiej ziemi Czapskiego (1990), zawierająca oprócz pozycji tytułowej Wspomnienia starobielskie i napisaną z myślą o niemieckim odbiorcy Walkę, Przeżyłam Oświęcim Żywulskiej i Książka o Kotymie Krakowieckiego. Zaraz potem zbiory nowel i opowiadań, które swą obozową całość rozpisują na teksty związane ze sobą za sprawą personalnego narratora (Borowski), estetyzacji odwołującej się na przykład do zabytków Rzymu ${ }^{30}$ albo chronologii opisywanych wydarzeń: Herminia Naglerowa i jej Kazachstańskie noce (1958). Pozostały jeszcze nowele lub opowiadania o tematyce obozowej, stanowiące część popularnych bezpośrednio po wojnie tomów prozatorskich, których autorzy starali się zapisać wojenno-okupacyjną rzeczywistość poprzez teksty dotyczące kluczowych wydarzeń lat 1939-1945 ${ }^{31}$. Dwa najważniejsze przykłady: Apel Andrzejewskiego z tomu Noc (1945) i Kantata Wojciecha Żukrowskiego z tomu Z kraju milczenia (1946).

\footnotetext{
${ }^{28}$ Pisałem o tym, cytując korespondencję Borowskiego, w książce Dwie prawdy..., dz. cyt., s. 102.

${ }^{29}$ Pamiętając o interpretacyjnych pomysłach T. Drewnowskiego, czytającego postać Vorarbeitera Tadka w kontekście wielkoimprowizacyjnych gestów Konrada z Dziadów cz. III, antyromantycznego Borowskiego opisywałem w konferencyjnym tekście Tadeusz Borowski. Antyromantyczny początek literatury polskiej po wojnie, wykorzystanym w Dwóch prawdach, dz. cyt., s. $62-76$.

${ }^{30}$ Zob. G. Morcinek, Listy spod morwy (Sachsenhausen-Dachau), wyd. 2, Literatura Polska, Katowice 1946. Pierwodr.: 1945, oraz tenże, Listy z mojego Rzymu, Biuro Prasowe Biskupa Polowego W.P., Rzym 1946.

${ }^{31}$ Standardowa kompozycja tematyczna takich tomów obejmowała: wrzesień 1939, obozy koncentracyjne, Holokaust i Powstanie Warszawskie.
} 
Wiedząc o tym, że polska literatura obozowa to nie tyle poezja, ile proza, zarówno epicka, jak i nowelistyczna ${ }^{32}$, pozostaje zapytać o dramat, czyli o obozowe sztuki pisane w kraju i na emigracji. Niewiele jest tu do wskazania ${ }^{33}$. Krajowe dramaty Ireneusza Iredyńskiego (na przykład bezpośrednio obozowe Jasetka-moderne, wydrukowane w 1962, wystawione w 1965, czy obozowe w pośredni sposób Zejście do piekła wystawione w 1964) ${ }^{34}$ więcej mówią o powojennym świecie, wykorzystując lagry do opisania go, niż o lagrach samych w sobie. Podobnie, czyli instrumentalnie, traktuje lager Tadeusz Hołuj. Pisząc Dom pod Oświęcimiem (z 1948 roku), więcej uwagi poświęca psychologii swoich postaci niż obozowej rzeczywistości, a jego sztuka Puste pole z roku 1963 przedstawia to, co złego (i sensacyjnego) dzieje się na terenie nieokreślonego byłego lagru wówczas, gdy przygotowywane jest tam muzeum. Dużo bardziej obozowa jest Stara gwardia Mieczysława Lurczyńskiego ${ }^{35}$, chociaż jej autor dla większości tych, którzy w ogóle mieli z jego twórczością do czynienia, pozostaje bardziej znany jako poeta i prozaik, a z dramatem wiąże go w największym stopniu wstęp do Pierścienia wielkiej damy Cypriana Norwida ${ }^{36}$ niż zapomniana, obozowa sztuka. Trudno więc przypuszczać, by dramat, podobnie jak poezja, stanowił jakąkolwiek genologiczną konkurencję dla prozy: rodzaju najważniejszego z punktu widzenia polskiej literatury obozowej. Nie zmienia to faktu, że konieczne jest uwzględnienie w syntezie możliwie wszystkich dramatów i całej dotyczącej obozów poezji. Także tej, która podobnie jak lagrowa i łagrowa proza stanowi przede wszystkim świadectwo obozowego losu, niezależnie od jej wartości literackiej ${ }^{37}$.

${ }^{32}$ Najlepsza nowelistyczna proza obozowa literatury polskiej to znowu Borowski, czyli lagrowe i dipisowskie teksty z Kamiennego świata.

${ }^{33}$ Dramat to rodzaj literacki, który - w odróżnieniu od prozy i poezji - tylko sporadycznie był wybierany do zapisywania obozowych wspomnień lub do tworzenia obozowej literatury.

34 „Bezpośrednio”, ponieważ akcja Jasetek-moderne rozgrywa się w obozie. „Pośrednio”, bo w Zejściu do piekła chodzi o lager zorganizowany w brazylijskiej dżungli przez hitlerowców zbiegłych z Europy. Pomijam w tym zestawieniu obóz, który sami dla siebie zgotowali członkowie wspólnoty opisanej przez Iredyńskiego w dramacie Trzecia pierś (pierwodr. w 1973, prapremiera w tym samym roku w Zurychu, premiera krajowa: 1975).

35 Zob. A. Morawiec, ,, Niech ludzie sądza”. O dramacie „, Stara gwardia” Mieczystawa Lurczyńskiego, w: Paryż - Londyn - Monachium - Nowy Jork. Powrześniowa emigracja niepodległościowa na mapie kultury nie tylko polskiej, pod red. V. Wejs-Milewskiej i E. Rogalewskiej, Trans Humana, Białystok 2009.

${ }^{36}$ Zob. C. Norwid, Pierścień wielkiej damy. Tragedia w 3-ch aktach, ze wstępem M. Lurczyńskiego, Polski Związek Wychodźctwa Przymusowego, Hanower 1945.

${ }^{37}$ Właśnie w tym miejscu chciałbym dodać, że nie zamierzam rozstrzygać, czy rację ma Bartłomiej Krupa, wskazując na wartość wszystkich, także nieprzekonujących literacko świadectw obozowych, czy Włodzimierz Bolecki, upominający się na Zjeździe Polonistów w 2004 roku o wyłączną obecność tekstów literackich w - nomen omen - literaturoznawczych opracowaniach dotyczących lagrów i łagrów. Napiszę jedynie o tym, co wydaje mi się oczywiste: najwięcej wiedzy o obozach dostarcza literatura piękna. Jest to wiedza pozwalająca zarówno na moralną, ale także na historyczną ocenę obozów. Reguła ta dotyczy także tych tekstów, które - przynajmniej 


\section{Periodyzacja}

Najcenniejsze z literackiego i historycznego punktu widzenia teksty obozowe literatury polskiej powstały w latach $1944-1948^{38}$. Najważniejsze wyjątki to Inny świat Herlinga-Grudzińskiego, po raz pierwszy opublikowany po angielsku w 1951 roku, a po polsku w roku 1953, oraz Obóz Wszystkich Świętych Tadeusza Nowakowskiego z 1957 roku. Wyjątki pozorne to Kazachstańskie noce Naglerowej z roku 1958, zawierające teksty z tomu Ludzie sponiewierani (1945), oraz $\mathrm{Na}$ nieludzkiej ziemi Czapskiego: proza, której najpełniejsze wydanie, o czym była już mowa, ukazało się co prawda dopiero w roku 1990, ale pierwsze pochodzi z roku 1949 i zawiera Wspomnienia starobielskie z 1944 roku.

Przełom 1956 roku nie przyniósł tematyce obozowej nic nowego oprócz kontrowersyjnej, nie tylko estetycznie, książki Stanisława Grzesiuka Pięć lat kacetu (1958). Lata 60., czyli - według Stanisława Burkota - trzecia fala literackiego zainteresowania wojną i okupacją $a^{39}$ to z punktu widzenia lagru wyłącznie Trismus Stanisława Grochowiaka z 1963 roku. W latach 60. i na początku 70. obozy pojawiły się w dramaturgii Ireneusza Iredyńskiego, o czym wspominałem w zakończeniu poprzedniego podrozdziału. Ważniejsze wydaje się jednak to, że zainteresowanie problematyką wojenno-okupacyjną, które wróciło na początku lat 70., ominęło tematykę obozową ${ }^{40}$. Rok 1975 przyniósł przełom w prozie, ale jej sylwiczne i opozycyjne konsekwencje nie były skupione ani na lagrach, ani na lagrach $^{41}$.

początkowo, jak w wypadku lagrowej prozy Borowskiego - powstawały wolne od wielkich, świadomie przygotowanych i konsekwentnie realizowanych ambicji literackich. Nie tylko historycy mogą mieć w tej sprawie inne zdanie.

${ }^{38}$ Wystarczy uwzględnić daty tekstów, na które najczęściej powołuję się w tym artykule. W dodatku diagnoza ta dotyczy zarówno literatury krajowej, jak i emigracyjnej.

${ }^{39}$ Zob. S. Burkot, Proza powojenna 1945-1987, wyd. 2 popr. i uzup., Wydawnictwa Szkolne i Pedagogiczne, Warszawa 1991, s. 66.

${ }^{40}$ Książki tak ważne jak Pamiętnik z powstania warszawskiego (1970) czy Chleb rzucony umartym (1971) dotyczą obozów. W przypadku prozy Mirona Białoszewskiego chodzi o obóz przejściowy w Pruszkowie, do którego po upadku powstania trafia on i jego najbliżsi. U Wojdowskiego nie sposób pominąć kończącej powieść akcji likwidacyjnej warszawskiego getta, oznaczającej wywożenie pozostających przy życiu Żydów do obozu zagłady w Treblince. Mimo to obie książki nie należą do literatury obozowej. Pierwsza, co zauważyła Maria Janion, wprowadza cywilny punkt widzenia na wojnę do polskiej literatury i pozwala Białoszewskiemu wrócić do - proszę wybaczyć anachronizm - głównego nurtu naszej kultury. Druga powinna być przede wszystkim czytana jako wyjątkowa, epicka opowieść o losach warszawskiego getta - od założenia go po zlikwidowanie. Pozostaje tylko dodać, że nieobecności obozu w prozie lat 70 . towarzyszy wielki powrót do sporu o polską literaturę lagrową, ponieważ właśnie wtedy ukazały się pierwsze wydania poświęconych Borowskiemu monografii A. Wernera (1971) i T. Drewnowskiego (1972).

${ }^{41}$ Podane w tym akapicie informacje dotyczą wyłącznie literatury krajowej. W tym samy czasie na emigracji, pomijając nazwiska i tytuły wymieniane już przeze mnie (chodzi m.in. o Nowa- 
Po 1989 podział na literaturę krajową i emigracyjną zdezaktualizował się m.in. dlatego, że na polski rynek wydawniczy trafiły wtedy legalnie publikowane teksty emigrantów dotyczące także problematyki łagrowej ${ }^{42}$. Z perspektywy roku 2016 istotniejsze dla obrazu literatury obozowej po '89 wydają się trzy inne, bardzo różne zjawiska. Najważniejszy wśród nich jest wielki powrót literatury Holokaustu ${ }^{43}$, pisanej przez twórców krajowych, jak i tych, którzy po wojnie z Polski wyjechali. Tematyka Zagłady, która towarzyszyła literaturze polskiej od opowiadań Adolfa Rudnickiego i cyklu Artura Sandauera, poprzez tetralogię Juliana Stryjowskiego, rodzinną żydowską wojnę Henryka Grynberga czy reportaże Hanny Krall, zaistniała jeszcze intensywniej po roku 1989, już nie tylko za sprawą pisarzy polskich żydowskiego pochodzenia, wśród których wymienić można osoby tak różne jak Roma Ligocka i Michał Głowiński, ale także za sprawą pisarzy żydowskich: Irit Amiel czy Idy Fink. Obóz nie odgrywa w tej literaturze pierwszoplanowej roli.

Podobnie jest $\mathrm{z}$ tekstami wpisującymi się w literaturę postpamięci. Najlepsze z nich: Fabryka muchołapek Andrzeja Barta z 2008 roku i Tworki Marka Bieńczyka z roku 1999, chociaż opowiadają albo o tym, co związane jest z gettem łódzkim, albo posługują się nośną metaforą psychiatrycznego szpitala, nie współtworzą beletrystyki obozowej, co akurat niepokoić nie powinno, jeśli weźmie się pod uwagę niepisane, ale stosowane prawo, odnoszące się zarówno do literatury lagrowej, jak i łagrowej, które mówi, że dawać świadectwo mogą wyłącznie wiarygodni świadkowie: ci, którzy obozu doświadczyli.

Jeszcze jeden argument, podwójny, określający sposób, w jaki Zagłada po 1989 roku była i jest tematem obecnym, któremu nie towarzyszy literackie zainteresowanie problematyką obozową ${ }^{44}$. $\mathrm{Z}$ jednej strony chodzi o swoistą leksykalizację zwrotu 'obóz koncentracyjny', powodującą używanie go jako środka stylistycznego, raczej alegorii niż metafory określającej sytuacje graniczne (traumatyczne,

kowskiego i Naglerową, ale także o Lurczyńskiego i Zofię Romanowiczową), nie dzieje się nic decydującego o wizerunku obozów w literaturze polskiej.

${ }^{42}$ Do wymienianych wcześniej krajowych edycji prozy B. Obertyńskiej i J. Czapskiego należy dodać przede wszystkim Inny świat, którego pierwsze, oficjalne, krajowe wydanie ukazało się nakładem wydawnictwa Czytelnik już w 1989 roku.

${ }^{43}$ Przede wszystkim jest to proza, ale nie sposób pominąć wierszy Irit Amiel, nie ma też powodu, by nie pamiętać o związanej z Szoa liryce H. Grynberga, ważnego dla pisania o Zagładzie przed i po 1989 roku.

44 Jeszcze kilka lat wcześniej, zwłaszcza przed rokiem 2010, napisałbym, że Holokaust to jedyny wciąż ważny i żywy temat wojenno-okupacyjny podejmowany przez literaturę polską. (Miałoby to znaczenie m.in. ze względu na nieobecność nowych literackich opracowań problematyki obozowej). Dzisiaj, na przełomie roku 2016 i 2017 należy dostrzec narastające zainteresowanie poetów polskich losami tzw. Żołnierzy Wyklętych. Piszą o nich m.in. Wojciech Wencel i Przemysław Dakowicz, a ich wiersze są na tyle ważne, by nie można było ich pominąć, pytając o miejsce drugiej wojny światowej we współczesnej literaturze polskiej. 
dramatyczne, albo po prostu trudne) ${ }^{45}$. Strona druga tego równania to obóz już nie jako leksem, ale jako rozbudowany znak kultury oznaczający opresję, funkcjonalny przy opisie społecznych patologii, także/zwłaszcza współczesnych ${ }^{46}$.

Literatura polska do tej pory nie poradziła sobie z Holokaustem, ale na tyle zapisała lagry i łagry w latach bezpośrednio powojennych, że temat ten nigdy potem nie stał się tak ważny i tak znakomicie literacko zrealizowany, jak miało to miejsce w latach 1944-1948. Nie zwalnia to jednak historyka literatury z pytania o związki między polską literaturą powojenną i polską literaturą obozową ${ }^{47}$.

${ }^{45}$ Na przykład: „Porzucenie jak obóz koncentracyjny” (A. Drotkiewicz, Paris, London, Dachau, Lampa i Iskra Boża, Warszawa 2004, s. 22) albo: „trauma center, Sarah Kane, Roland Barthes, obóz zagłady, jednym słowem chujowo" (tamże, s. 26). Tymi cytatami posłużyłem się w tekście Bezradność. Polska proza wobec II wojny światowej, wygłoszonym na konferencji Pokój/ wojna - humanistyka wobec wyzwań współczesności (Zielona Góra, listopad 2015). Wykorzystałem wówczas także fragment dramatu D. Masłowskiej Między nami dobrze jest, w którym sposób mówienia o obozie praktykowany przez MAŁĄ METALOWĄ DZIEWCZYNKĘ sugeruje, że nie ma ona o tym miejscu żadnej wiedzy. „MAŁA METALOWA DZIEWCZYNKA: W końcu cały dzień siedzi babcia w domu bez windy, do nikogo ust otworzyć, więc jak wracam ze szkoły i aż do wieczora siedzę przed telewizorem, to nie mam czasu tej starej brukwi jeszcze gdzieś wozić! Rączo furgotały na wietrze moje warkoczyki, gdy tak sobie nie szłyśmy jesiennym parkiem, ona opowiadała mi te swoje pyszne historie, jak pojechała na ten obóz koncentracyjny. Moim zdaniem trochę zżyna z Czterech pancernych i psa i Allo Allo, ale niech jej tam. W końcu jest postmodernizm" (D. Masłowska, Między nami dobrze jest, w: taż, Dwa dramaty zebrane, Lampa i Iskra Boża, Warszawa 2010, s. 74). Tym razem zestaw „obozowych” cytatów uzupełnię fragmentami powieści Jakuba Żulczyka, urodzonego w tym samym roku co Masłowska, autora popularnego nie tylko wśród młodych czytelników. Pierwsze zdanie dotyczy licealnej nauczycielki lubianej przez uczniów: „Nikt nie wie, o czym pani Ania mówi, ale za to wygląda jak aktorka, która mogłaby zagrać zakonnicę karmiącą miodem uciekinierów z obozów koncentracyjnych” (J. Żulczyk, Radio Armageddon, wyd. 2 zm., Świat Książki, Warszawa 2015, s. 31. Pierwodr.: 2008). Zdanie drugie: „Niektórzy uważają, że handlarze heroiną są źli, zarażeni złem strażników z obozów koncentracyjnych" (J. Żulczyk, Ślepnąc od światet, Świat Książki, Warszawa 2014, s. 168). Masłowska, niezależnie od stosowanej przez siebie stylistycznej konwencji, kwestię obozów traktuje bardziej serio niż Drotkiewicz. O Żulczyku chciałbym napisać to samo. Chciałbym.

46 Tylko jeden przykład, ale za to spektakularny i z aneksem: Skaza Magdaleny Tulli (2006), książka w której sposób traktowania obcych (chciałoby się napisać uchodźców) przedstawiony jest przy użyciu rozwiązań znanych nie tylko z Niemiec lat 30. XX wieku, a obóz, zwłaszcza komora gazowa, odgrywa w tej opowieści istotną rolę. Aneks: Proza Pawła Huellego Szczęśliwe dni z tomu Pierwsza miłość i inne opowiadania (1996) inaczej wywołuje kwestię pamięci historycznej, a zwłaszcza miejsca, jakie zajmują w niej obozy. Wagony transportujące ludzi do Auschwitz pojawiają się w tekście Huellego obok wagonów niemieckich przesiedleńców i wagonów repatriantów ze Wschodu. Intencja tego zabiegu wydaje się oczywista: chodzi o przywrócenie naszej (narodowej?, europejskiej?) pamięci tych traum, o których w PRL-u nie można było mówić. Czy jednak ubocznym efektem tego uzasadnionego wyboru nie jest zatarcie wyjątkowości tego, co zdarzyło się w Auschwitz?

${ }^{47}$ Pisząc o polskiej literaturze powojennej, mam na myśli nie tylko jej właściwą postać, wyznaczoną przez daty 1944-1989, ale także literaturę współczesną, która trwa od roku 1989. 


\section{Komparatystyka}

Warłam Szałamow, Primo Levi oraz Imre Kertész. Historycznoliteracka synteza polskiej literatury obozowej powinna zawierać materiał konfrontujący teksty Tadeusza Borowskiego i innych przynajmniej z łagrowo-lagrowym dorobkiem trzech wymienionych pisarzy. Pierwsze próby były już podejmowane. $\mathrm{O}$ autorze Opowiadań kołymskich i Borowskim pisała m.in. Anna Łukowska, zrażona jednostronnością drugiego $\mathrm{z}$ nich ${ }^{48}$. Autora $C z y$ to jest człowiek wymienia zarówno Magdalena Swat-Pawlicka, analizując casus muzułmana w systemie koncentracyjnym $^{49}$, jak i Sławomir Buryła, określając relację między prozą Borowskiego i Holokaustem ${ }^{50}$, a nie są to przecież przywołania jedyne. Kertész pojawia się częściej, ale, tak jak w przypadku poprzedniego twórcy, powołam się tylko na dwa teksty: kolejny z tematycznego numeru „Tekstów Drugich"51 i kolejny Sławomira Buryły ${ }^{52}$.

Wobec znaczenia tego, co napisało wielu, łatwiej stawia się wymagania dotyczące opracowań następnych, niezbędnych, bo przecież to, co obozowe ani nie było, ani nie może być traktowane jako wyłącznie polskie, a synteza omawiająca naszą literaturę lagrową i łagrową to tylko jeden $\mathrm{z}$ etapów poprzedzających powstanie opracowania już nie tylko europejskiego, ale uwzględniającego obozy funkcjonujące na całym świecie, najpierw w latach 1939-1945. Jeśli badania te będą uwzględniać współczesne przywołania obozów w literaturze powszechnej, ich rezultatem powinny być analizy i takich cytatów:

Widzisz. Świat to w gruncie rzeczy obóz pracy przymusowej, z którego codziennie kilku robotników - całkowicie niewinnych, wybranych losowo - prowadzonych jest na egzekucję. Nie wydaje mi się, że to tylko mój sposób widzenia. Wydaje mi się, że tak jest. Czy są możliwe jakieś inne poglądy? Oczywiście. Czy któryś z nich wytrzymuje krytykę? $\mathrm{Nie}^{53}$.

\footnotetext{
48 Zob. A. Łukowska, Borowski i Szałamow - dwie dole, „Kultura Niezależna” 1989, nr 52.

${ }^{49}$ Zob. M. Swat-Pawlicka, Z inkubatora systemu. Casus muzulmana w systemie koncentracyjnym, ,Teksty Drugie” 2004, nr 5.

${ }^{50}$ Zob. S. Buryła, Proza Tadeusza Borowskiego wobec Holocaustu, „Ruch Literacki” 2004, z. 3.

${ }^{51}$ Zob. J. Jastrzębska, Imre Kertész - węgierski wariant dyskursu o Holocauście, „Teksty Drugie" 2004, nr 5.

${ }^{52}$ S. Buryła wspomina o Kertészu we Wstęie do pierwszego tomu Próz Borowskiego (Kraków 2004), określając go jako dłużnika autora Pożegnania z Marią.

${ }^{53}$ C. McCarthy, Sunset Limited. Powiesśc w formie dramatu, przeł. R. Sudół, Wydawnictwo Literackie, Kraków 2013, s. 102. Pierwodr. amerykańskiego oryginału: 2006.
} 


\section{Synteza}

Nie dość, że historia literatury, jaką znamy i pamiętamy, jest już niemożliwa, to jeszcze zapisywanie jej w odniesieniu do tekstów obozowych napotyka na trudności partykularne, związane wyłącznie ze specyfiką tego rodzaju piśmiennictwa. Z drugiej jednak strony, czy może dziwić pragnienie syntetycznego omawiania (jeśli nie omówienia) tego, co dotyczy nie tylko zjawiska konstytutywnego dla kondycji powojennego świata, ale także dla kondycji rodzaju ludzkiego. Moim zdaniem nie pozostaje nic innego, jak tylko zmagać się z niemożliwym, jeśli historycznoliteracka synteza polskiej literatury obozowej rzeczywiście jest nie do napisania. Realne pozostaje przecież naszkicowanie literackiej mapy obozów: zidentyfikowanych i nazwanych, które funkcjonowały w latach 1939-1945 na ziemiach przedwojennej lub przynajmniej powojennej Polski. Tak samo w naszym zasięgu pozostaje zgromadzenie całej literatury obozowej napisanej po polsku: krajowej, emigracyjnej, wiarygodnej literacko i pełniącej funkcję quasi-literackiego świadectwa.

Do analizy tego materiału też jesteśmy gotowi, ponieważ mamy za sobą i ze sobą bezcenne prace wyznaczające kulturowy (środowiskowy i edytorski) kontekst literatury obozowej (Drewnowski), mamy znakomite interpretacje tejże (Werner, Zygmunt Ziątek) ${ }^{54}$ i przekonujące ich dekonstrukcje (Krzysztof Kłosiński) ${ }^{55}$, a jeśli komuś przeszkadza, że podane przykłady dotyczą przede wszystkim Borowskiego (bo przecież także literatury martyrologicznej), mamy postulat Bartłomieja Krupy, domagającego się czytania tekstów obozowych jako materiału pozwalającego na konstruowanie strukturalistyczno-społecznego modelu tego, co lagrem jest.

Czy ten stan posiadania wystarczy, by przezwyciężyć powody, dla których synteza polskiej literatury obozowej do tej pory nie powstała? Przecież znaczenie lagrowej prozy Borowskiego wciąż sprawia, że synteza wydaje się zbędna, a różnice między obozową literaturą pisaną w kraju i na emigracji sugerują, że jest niemożliwa. Pozostaje Holokaust: niezapisany przez ,polskich pisarzy polskiego pochodzenia". To z jego powodu synteza wydaje się konieczna, ponieważ opracowanie jej dobitnie pokaże brak tekstów obozowych, które biorą pod uwage wyjątkowy los Żydów. Wykonanie tego zadania nie zmieni stanu literatury i jako takie może się wydawać niepotrzebne ${ }^{56}$, ale próbować trzeba: i po to, by synte-

\footnotetext{
${ }^{54}$ Zob. Z. Ziątek, „Pamięć przechowuje tylko obrazy”. Tadeusz Borowski, w: Sporne postaci polskiej literatury współczesnej, pod red. A. Brodzkiej, Wydawnictwo Instytutu Badań Literackich, Warszawa 1994.

${ }^{55}$ Zob. K. Kłosiński, ,Proszę państwa do gazu”, w: tenże, W stronę inności. Rozbiory i debaty, Wydawnictwo Uniwersytetu Śląskiego, Katowice 2006.

${ }^{56} \mathrm{Nie}$ wiem, czy synteza, pokazując to, czego brakuje, skłoni twórców do wypełnienia tej luki. Problem polega nie tylko na perswazyjnej (nie)skuteczności historycznoliterackich diagnoz, ale
} 
za powstała, i po to, byśmy pamiętali. Jeśli jednak historycznoliteracka synteza polskiej literatury obozowej miałaby zwolnić nas z obowiązku pamiętania, lepiej żeby nikt jej nie napisał.

\section{Bibliografia}

Amiel Irit, Egzamin z Zagłady, Oficyna Bibliofilów, Łódź 1994.

Amiel Irit, Nie zdążłam, Oficyna Bibliofilów, Łódź 1998.

Amiel Irit, Wdychać głęboko, Świat Literacki, Izabelin 2002.

Appelbaum Anne, Gułag, przeł. Jakub Urbański [rozdz. 1 - Małgorzata Claire Wybieralska], Świat Książki, Warszawa 2005.

Białoszewski Miron, Pamiętnik z powstania warszawskiego, Państwowy Instytut Wydawniczy, Warszawa 1970.

Borowski Tadeusz, Pisma w czterech tomach, pod red. Tadeusza Drewnowskiego, Justyny Szczęsnej, Sławomira Buryły, Wydawnictwo Literackie, Kraków 2003-2005.

Borowski Tadeusz, Utwory zebrane, red. nacz. Jerzy Andrzejewski, t. 3: Krytyka literacka i artystyczna, Państwowy Instytut Wydawniczy, Warszawa 1954.

Broszkiewicz Jerzy, Oczekiwanie, Wiedza, Warszawa 1948.

Burkot Stanisław, Proza powojenna 1945-1987, wyd. 2 popr. i uzup., Wydawnictwa Szkolne i Pedagogiczne, Warszawa 1991.

Buryła Sławomir, Proza Tadeusza Borowskiego wobec Holocaustu, „Ruch Literacki” 2004, z. 3, s. 293-307.

Czaplejewicz Eugeniusz, Polska literatura łagrowa, Wydawnictwo Naukowe PWN, Warszawa 1992.

Czas ciekawy, czas niespokojny. Z Leszkiem Kołakowskim rozmawia Zbigniew Mentzel, cz. 1, Znak, Kraków 2007.

Czuchnowski Marian, Tyfus, teraz stowiki, Modern Writing, Londyn 1951.

Dakowicz Przemysław, Łączka, Arcana, Kraków 2013.

Drewnowski Tadeusz, Literatura polska 1944-1989. Próba scalenia: obiegi-wzorce-style, wyd. 2 popr. i uzup., Universitas, Kraków 2004.

Drewnowski Tadeusz, Próba scalenia. Obiegi - wzorce - style, Wydawnictwo Naukowe PWN, Warszawa 1997.

Drewnowski Tadeusz, Ucieczka z kamiennego świata. O Tadeuszu Borowskim, wyd. 3, Państwowy Instytut Wydawniczy, Warszawa 1992.

Drotkiewicz Agnieszka, Paris, London, Dachau, Lampa i Iskra Boża, Warszawa 2004.

Grynberg Henryk, Rysuję w pamięci, a5, Poznań 1995.

Herling-Grudziński Gustaw, Inny świat. Zapiski sowieckie, Czytelnik, Warszawa 1989.

Huelle Paweł, Szczęśliwe dni, w: Huelle Paweł, Pierwsza miłość i inne opowiadania, Puls, Londyn 1996, s. 104-151.

Janion Maria, Wojna i forma, w: Janion Maria, Płacz generała. Eseje o wojnie, Wydawnictwo Sic!, Warszawa 1998, s. 23-126. Pierwodr. artykułu: 1976.

także (przede wszystkim?) na tym, że coraz trudniej o tych, którzy obóz przeżyli i mogliby o nim napisać, uwzględniając wyjątkowość losu eksterminowanych Żydów. Literatura postpamięci nie wydaje się w tej sprawie wystarczająca. 
Jastrzębska Jolanta, Imre Kertész - węgierski wariant dyskursu o Holocauście, „Teksty Drugie” 2004, nr 5, s. 152-167.

Kizny Tomasz, Gułag, współpr. Dominique Roynette, wstęp Norman Davies, Siergiej Kowalow, Nicolas Werth, IPN - Komisja Ścigania Zbrodni przeciwko Narodowi Polskiemu, Fundacja Picture Doc, Warszawa 2015.

Kossak Zofia, Z otchtani, Instytut Wydawniczy PAX, Warszawa 1958.

Kossak Zofia, Z otchtani. Wspomnienia z lagru, Wydawnictwo Księgarni Wł. Nagłowskiego, Częstochowa-Poznań 1946.

Kraśniewska Wiktoria, Po wyzwoleniu... (1944-1956), Instytut Literacki, Paryż 1985.

Krupa Bartłomiej, Wspomnienia obozowe jako specyficzna odmiana pisarstwa historycznego, Universitas, Kraków 2006.

Kulesza Dariusz, Dwie prawdy. Tadeusz Borowski i Zofia Kossak wobec obrazu wojny w polskiej prozie lat 1944-1948, Trans Humana, Białystok 2006.

Kulesza Dariusz, W poszukiwaniu istoty rzeczy. Studia i portrety, Alter Studio, Białystok 2015.

Łukowska Anna, Borowski i Szałamow - dwie dole, „Kultura Niezależna” 1989, nr 52, s. 42-64.

Masłowska Dorota, Między nami dobrze jest, w: Masłowska Dorota, Dwa dramaty zebrane, Lampa i Iskra Boża, Warszawa 2010, s. 65-122.

McCarthy Cormac, Sunset Limited. Powieść w formie dramatu, przeł. Robert Sudól, Wydawnictwo Literackie, Kraków 2013. Pierwodr. amerykańskiego oryginału: 2006.

Morawiec Arkadiusz, „Niech ludzie sądza”. O dramacie „Stara gwardia” Mieczysława Lurczyńskiego, w: Paryż - Londyn - Monachium - Nowy Jork. Powrześniowa emigracja niepodległościowa na mapie kultury nie tylko polskiej, pod red. Violetty Wejs-Milewskiej i Ewy Rogalewskiej, Trans Humana, Białystok 2009, s. 655-679.

Morcinek Gustaw, Listy spod morwy (Sachsenhausen-Dachau), wyd. 2, Literatura Polska, Katowice 1946.

Morcinek Gustaw, Listy z mojego Rzymu, Biuro Prasowe Biskupa Polowego W.P., Rzym 1946.

Morka Andrzej, Doświadczenie Boga w Gułagu, Wydawnictwo Diecezjalne i Drukarnia Diecezji Sandomierskiej, Sandomierz 2007.

Norwid Cyprian, Pierścień wielkiej damy. Tragedia w 3-ch aktach, ze wstępem Mieczysława Lurczyńskiego, Polski Związek Wychodźctwa Przymusowego, Hanower 1945.

Obertyńska Beata, $W$ domu niewoli, Instytut Wydawniczy Pax, Warszawa 1991.

Obozy hitlerowskie na ziemiach polskich 1939-1945. Informator encyklopedyczny, Państwowe Wydawnictwo Naukowe, Warszawa 1979.

Pankowski Marian, Z Auszwicu do Belsen. Przygody, Czytelnik, Warszawa 2000.

Pisarze polsko-żydowscy XX wieku. Przybliżenia, pod red. Mieczysława Dąbrowskiego i Aliny Molisak, Elipsa, Warszawa 2006.

Pożegnanie z Tuśka, notowali Krystyna Bratkowska i Michał Cichy, „Gazeta Wyborcza” 1995, nr 24, s. $14-16$.

Romanowiczowa Zofia, Łagodne oko błękitu, Libella, Paris 1968.

Romanowiczowa Zofia, Przejście przez Morze Czerwone, Libella, Paris 1960.

Romanowiczowa Zofia, Trybulacje Proboszcza P., Algo, Archiwum Emigracji, Toruń 2001.

Rudnicki Adolf, Szekspir, Książka, Warszawa 1948.

Sandauer Artur, O sytuacji pisarza polskiego pochodzenia żydowskiego w XX wieku (rzecz, która nie ja powinienem byt napisać...), Czytelnik, Warszawa 1982. 
Sariusz-Skąpska Izabella, Polscy świadkowie GUŁagu. Literatura łagrowa 1939-1989, wyd. 3, Universitas, Kraków 2012.

Skarga Barbara, Po wyzwoleniu... (1944-1956), wyd. 2 krajowe, W drodze, Poznań 1990.

Sołżenicyn Aleksander, Archipelag GUŁag 1918-1956. Próba analizy literackiej, cz. 1-2, przeł. Michał Kaniowski, Instytut Literacki, Paryż 1974.

Swat-Pawlicka Magdalena, Z inkubatora systemu. Casus muzulmana w systemie koncentracyjnym, „Teksty Drugie” 2004, nr 5, s. 64-77.

Szczęsna Justyna, Tadeusz Borowski - poeta, Poznańskie Studia Polonistyczne. Seria Literacka, Poznań 2002.

Szmaglewska Seweryna, Dymy nad Birkenau, Czytelnik, Warszawa 1945.

„Teksty Drugie” 2004, nr 5.

Tulli Magdalena, Skaza, W.A.B., Warszawa 2006.

Wencel Wojciech, De profundis, Arcana, Kraków 2010.

Werner Andrzej, Zwyczajna apokalipsa. Tadeusz Borowski i jego wizja świata obozów, Czytelnik, Warszawa 1971.

Wojdowski Bogdan, Chleb rzucony umartym, Państwowy Instytut Wydawniczy, Warszawa 1971. Wojdowski Bogdan, Judaizm jako los, „Puls” 1993, nr 3, s. 67-78.

Żulczyk Jakub, Radio Armageddon, wyd. 2, zm., Świat Książki, Warszawa 2015.

Żulczyk Jakub, Ślepnac od świateł, Świat Książki, Warszawa 2014.

Żywulska Krystyna, Przė̇yłam Oświęcim, Wiedza, Warszawa 1946.

\section{Dariusz Kulesza}

\section{Polish Literature on the Concentration Camp Experience A Few Questions on a Non-Existent Synthesis}

\section{(Summary)}

The author of the paper wonders why nobody so far has attempted a historical-literary synthesis of Polish literature concerning the concentration camp experience in general, and the labour camp experience in particular, as the latter has an obvious potential for a proto-synthesis. The question is followed by subjective answers that build upon the significance of Tadeusz Borowski's prose, the uniqueness of the Holocaust, and differences between the records of the camp experience in Poland and abroad. In its central part, the paper points to a certain possibility at our disposal to - irrespective of almost insurmountable obstacles - at least start the aforementioned synthesis. This can be done by the application of the external criteria: historical-geographical (what camps, when and where) and historical-literary, which would include such perspectives and categories as periodization, literary genres and comparative studies.

Keywords: polish literature on concentration camps; historical and literary synthesis; Tadeusz Borowski; the Holocaust 